\title{
ASKING THE RIGHT QUESTION IN CITY OF HAYS V. VOGT
}

\author{
Neal Modi ${ }^{*}$
}

I. Introduction .............................................................................. 237

II. Background ................................................................................ 240

III. The Nature of Fifth Amendment Rules ............................. 241

IV. The Difference With Immunity ........................................... 244

V. Closing the Loop ...................................................................... 250

VI. Conclusion ............................................................................... 253

\section{INTRODUCTION}

This term, the U.S. Supreme Court heard argument in City of Hays, Kansas v. Vogt. ${ }^{1}$ In that case, the City is asking the Court to decide whether the Fifth Amendment's Self-Incrimination Clause (the "Clause") applies to pretrial proceedings. Prompting the Court to hear the case is an extensive circuit split. The Third, Fourth, and Fifth Circuits have each held that a violation of the Clause may only occur at a criminal trial. ${ }^{2}$ The Second, Seventh, Ninth, and now Tenth Circuits, meanwhile, have held

* J.D., University of Virginia School of Law, 2017; B.A., University of Virginia, 2012. All views expressed herein are my own and do not reflect the views or opinions of my employer. I would like to thank the wonderful members of the Seton Hall Circuit Review for their helpful feedback and guidance. All errors are my own.

1198 L. Ed. 2d 781 (Sep. 28, 2017).

2 See Renda v. King, 347 F.3d 550, 552 (3d Cir. 2003) ("[A] plaintiff may not base a $\S 1983$ claim on the mere fact that the police questioned her in custody without providing Miranda warnings when there is no claim that the [\$1983] plaintiff's answers were used against her at trial.”); Burrell v. Virginia, 395 F.3d 508, 514 (4th Cir. 2005) (“[The plaintiff] does not allege any trial action that violated his Fifth Amendment rights; thus, ipso facto, his claim fails on the [Chavez] plurality's reasoning."); Murray v. Earle, 405 F.3d 278, 285 n. 11 (5th Cir. 2005) (citations omitted) (though distinguishing its case from Chavez, the court held that absent a coerced confession's use at trial, "plaintiffs do not have a Fifth Amendment claim against law-enforcement officials who have elicited unlawful confessions"). 
that certain uses of compelled or coerced statements outside a criminal trial violate the Clause. ${ }^{3}$

It is not clear which side has the better argument. The circuits that have contained a violation of the Clause to a criminal trial have referred to Justice Thomas's opinion in Chavez v. Martinez. ${ }^{4}$ There, Justice Thomas suggested that the government violates the privilege only when it introduces the defendant's testimony against him during a "criminal case"-an event that "at the very least requires the initiation of legal proceedings." "In support of this position, one circuit has added that the meaning of the Clause's "witness against [himself]" limits the Clause's application to within a criminal trial. ${ }^{6}$

In contrast, the Second, Seventh, Ninth, and Tenth Circuits have declined to place such heavy emphasis on Chavez, looking elsewhere in the Constitution for an answer instead. The Second Circuit, for example, referred to the Sixth and Eighth Amendments to conclude that, like an actual trial, pretrial "bail hearings fit comfortably within the sphere of adversarial proceedings closely related to trial." 7 Therefore, the Clause prohibits the use of compelled testimony in pretrial bail hearings. The Tenth Circuit arrived at a similar conclusion in Vogt. It noted that the omission of the words "criminal prosecution" and "trials" in the Fifth Amendment - words which appear in the trial-focused Sixth and Seventh Amendments, respectively-indicates that the Founders intended the Clause's "criminal case" to cover more than the trial itself. ${ }^{8}$ Moreover, the word "witness," the Tenth Circuit added, must extend beyond a criminal trial. ${ }^{9}$ After all, at the time of the Fifth Amendment's ratification, criminal defendants could not serve as a witness at their own trial. ${ }^{10}$ To restrict the Clause's application to criminal trials alone, therefore, would give a

3 See Sornberger v. City of Knoxville, 434 F.3d 1006, 1027 n. 15 (7th Cir. 2006) (refusing to hold "that the right against self-incrimination cannot be violated unless a confession is introduced in the prosecution's case-in-chief at trial before the ultimate finder of fact”); Higazy v. Templeton, 505 F.3d 161, 171, 173 (2d Cir. 2007) (noting that the use of a coerced statement before a trial or grand jury can violate the Fifth Amendment); Stoot v. City of Everett, 582 F.3d 910, 925 (9th Cir. 2009) (noting that where "[a] coerced statement . . . has been relied upon to file formal charges against the declarant ...." the Fifth Amendment has been violated); Vogt v. City of Hays, 844 F.3d 1235, 1237 (10th Cir. 2017).

4 See Renda, 347 F.3d at 558; Burrell, 395 F.3d at 513-14.

5 Chavez v. Martinez, 538 U.S. 760, 766 (2005).

6 Renda, 347 F.3d at 557 (citing Guiffre v. Bissell, 31 F.3d 1241, 1256 (3d Cir. 1994)).

7 Higazy, 505 F.3d at 172-73 (citing United States v. Abuhamra, 389 F.3d 309, 323 (2d Cir. 2004)).

8 Vogt, 844 F.3d at $1242-44$.

9 Id. at 1246.

10 See Ferguson v. Georgia, 365 U.S. 570, 573-74 (1961) (stating that when the United States was formed, "criminal defendants were deemed incompetent as witnesses"). 
meaning to "witness" that did not exist when the Fifth Amendment was ratified.

Yet despite these opinions' analysis, each overlooked a critical issue: the constitutional character of Fifth Amendment rules. The failure to discuss the character (or nature) of these rules-namely, Miranda warnings $^{11}$ and immunity - is significant. Indeed, whether a pretrial hearing can give rise to a Fifth Amendment violation, this Article turns on: (1) whether these rules are guaranteed by the Constitution and (2) if they are, how broadly the Court is ready to interpret them. Until now, no party to these cases has thoroughly discussed this detail. It is important that the Supreme Court, set to decide Vogt this term, does not do the same.

Part I provides the factual backstory to Vogt. Part II then summarizes the Court's views on the constitutional nature of Fifth Amendment rules. This Part investigates whether the Court characterizes Fifth Amendment rules as prophylactic safeguards, extending beyond the trial right at the core of the Fifth Amendment and thus lacking any constitutional significance of their own, or whether the Court considers Fifth Amendment rules, and particularly immunity, as part and parcel of the Clause's constitutional promise.

Part III continues that discussion, turning its focus onto immunity. It will spell out important differences between use/derivative use immunity (the issue in Vogt) and Miranda warnings (the issue in Chavez v. Martinez). The purpose of this comparison is to demonstrate that certain differences between immunity and Miranda warnings likely grant plaintiffs who successfully allege a violation of use/derivative use immunity ("immunity") $\S 1983$ relief. ${ }^{12}$ Thus, this Part suggests that, in cases implicating immunity, any interpretation of the Clause's phrases "any criminal case" and "a witness against himself" should be co-extensive with the scope of barred uses under immunity.

Finally, Part IV will complete the loop. Part IV lays out arguments for whether the use of an immunized statement in a pretrial probable cause hearing violates the immunity doctrine and thus the Clause. This Part reveals that an answer to this question implicates a complicated circuit

\footnotetext{
11 Miranda v. Arizona, 384 U.S. 436, 466 (1966).

12 A valid issue is whether, despite the availability of a $\S 1983$ remedy, plaintiffs can overcome prosecutor's absolute immunity, see Imbler v. Pachtman, 424 U.S. 409, 427 (1976) (extending the absolute immunity prosecutors enjoyed under common law malicious prosecution suits to suits against prosecutors under $\S 1983$ ). It is doubtful. Of course, Vogt is a different case since the defendant in the $\$ 1983$ action is a municipality, which can be held liable under $\S 1983$. See Owen v. City of Independence, 445 U.S. 622, 638 (1980) ("there is no tradition of immunity for municipal corporations, and neither history nor policy supports a construction of $\S 1983$ that would justify the qualified immunity accorded the city of Independence by the Court of Appeals.").
} 
split of its own: what is the scope of immunity's protection? This Article submits that to arrive at a proper outcome in Vogt, the Court should answer that separate but equally important question.

\section{BACKGROUND}

In Vogt, the respondent, Matthew Vogt, had served as a police officer for the City of Hays, Kansas (the "City" or "Hays"). ${ }^{13}$ In a job interview with the City of Haysville, another jurisdiction in Kansas, Vogt revealed that he had, while on duty with the Hays police force, obtained and kept a knife. ${ }^{14}$ After the City of Haysville conditioned Vogt's hire on the disclosure and return of the knife to the Hays police department, Vogt reported the knife to his superior in Hays. ${ }^{15}$

Upon writing a "vague, one-sentence" statement about the knife, ${ }^{16}$ the Hays police chief demanded that Vogt provide more detail or else face termination. ${ }^{17}$ Under this threat, Vogt complied. Eventually, the State of Kansas, provided with Vogt's statements by the City, pressed two felony charges against Vogt related to the knife, introducing the statements he made to the Hays police chief at a pretrial probable cause hearing in that matter. ${ }^{18}$ At that hearing, the court dismissed the two felony charges brought against Vogt. ${ }^{19}$

With no criminal proceeding in the way, Vogt filed a civil rights claim under 42 U.S.C. $\S 1983^{20}$ (" $\$ 1983$ ") against the City, the City of Haysville, and four individual officers. ${ }^{21}$ The basis of Vogt's claim was (1) that the defendants compelled him to make incriminating statements by threatening to terminate his employment if he did not do so; and (2) that those statements were used against him, contrary to the Clause, in a

13 Vogt, 844 F.3d at 1238.

14 Id.

$15 I d$.

$16 I d$.

$17 I d$.

18 Id.

19 Vogt, 844 F.3d at 1238.

2028 U.S.C. $§ 1983$ reads: "Every person who, under color of any statute, ordinance, regulation, custom, or usage, of any State or Territory or the District of Columbia, subjects, or causes to be subjected, any citizen of the United States or other person within the jurisdiction thereof to the deprivation of any rights, privileges, or immunities secured by the Constitution and laws, shall be liable to the party injured in an action at law, suit in equity, or other proper proceeding for redress, except that in any action brought against a judicial officer for an act or omission taken in such officer's judicial capacity, injunctive relief shall not be granted unless a declaratory decree was violated or declaratory relief was unavailable. For the purposes of this section, any Act of Congress applicable exclusively to the District of Columbia shall be considered to be a statute of the District of Columbia."

21 Vogt, 844 F.3d at 1238. 
probable cause hearing. ${ }^{22}$ The federal district court dismissed each of Vogt's claims, holding that because "the compelled statements were never introduced against [Vogt] at trial," Vogt had "fail[ed] to state a violation of his Fifth Amendment rights." 23

The Tenth Circuit disagreed in part. ${ }^{24}$ Though it dismissed the claims against the City of Haysville and the four individual officers, ${ }^{25}$ it concluded that, under Garrity v. New Jersey, ${ }^{26}$ Hays compelled Vogt when its police chief pressed him to provide a detailed statement or else face dismissal. ${ }^{27}$ City's subsequent disclosure of Vogt's statement to Kansas state authorities, the court added, began a series of events that led to the compelled testimony's use in a probable cause hearing. ${ }^{28}$ Referring to holdings from the Seventh and Ninth Circuits, as well as its own textual interpretation of the Clause, the Tenth Circuit then held that the Fifth Amendment's "criminal case" extends to probable cause hearings. ${ }^{29}$ Vogt had therefore made a valid Fifth Amendment claim against the City. ${ }^{30}$

Now before the Supreme Court, the City does not directly contest that Vogt's statement was compelled under Garrity. ${ }^{31}$ Instead, the City asks the Court to decide whether the Clause's protection extends to a pretrial probable cause hearing. ${ }^{32}$

\section{THE NATURE OF FIFTH AMENDMENT RULES}

The first step to answering this question is to determine the genesis of the Fifth Amendment's rules; in particular, Miranda warnings and immunity. Determining whether these rules are non-constitutional prophylactics or are constitutional rules themselves (and thus a proper

22 Id.

23 Vogt v. City of Hays, 2015 U.S. Dist. LEXIS 132647 at *11-12 (D. Kan. Sep. 30, 2015).

24 Vogt, 844 F.3d at 1246.

25 Id. at $1246-49$.

26385 U.S. 493, 500 (1966) (an individual's protection under the Fifth and Fourteenth Amendments prohibits the use of statements obtained upon threat of removal from public office). It is well established that a public official, asked to speak or face termination, does not need to invoke silence to receive protection under the Fifth Amendment. The public official's statements are automatically cloaked with use/derivative use immunity. For more, see also Peter Westen, Answer Self-Incriminating Questions or Be Fired, 37 Am. J. Crim. L. 97, 103, 108-109 (2010).

27 Vogt, 844 F.3d at 1250-52 (concluding that "Vogt had adequately pleaded that Hays had started a chain of events that resulted in violation of the Fifth Amendment").

28 Id.

29 Id. at $1246-52$.

$30 \mathrm{Id}$.

31 Resp. Brief for Petitioner at 2; Brief for Petitioner at 2, 11 n.1, City of Hays v. Vogt, 138 S. Ct. 55 (2017) (No. 16-1495), 2017 WL 5495450, at *3 n.1 (noting that Garrity immunity likely does apply to Vogt's statements).

32 Pet. at 4-5. 
basis for $\S 1983$ relief) is crucial to deciding if the outcome in Vogt turns on the scope of the immunity doctrine itself.

In Chavez, Justice Thomas, writing for a plurality comprised of Chief Justice Rehnquist and Justices O'Connor and Scalia, held that "rules [in Chavez, Miranda warnings] designed to safeguard a constitutional right ... do not extend the scope of the constitutional right itself, just as violations of judicially crafted prophylactic rules do not violate the constitutional rights of any person." ${ }^{33}$ One year later, in United States $v$. Patane, Justice Thomas continued this point. ${ }^{34}$ He again emphasized that the Fifth Amendment's Miranda warnings "necessarily sweep beyond the actual protections of the Self-Incrimination Clause." 35 Various exceptions to the Miranda doctrine, he added, illustrate that the Clause does not, on its own, extend to pretrial events. ${ }^{36}$ After all, the Miranda safeguard, and its accompanying exclusionary rule, is only required if it protects the trial right at the core of the Fifth Amendment, he added. ${ }^{37}$ Where it does not, the exclusion of un-Mirandized testimony is unnecessary. ${ }^{38}$

However, not all justices have joined Justice Thomas's views about Fifth Amendment rules. ${ }^{39}$ In fact, besides Justice Thomas himself, no present member of the Court has ever fully subscribed to his Chavez opinion. Rather, the Court today more likely fits between two opinions on the subject. The first was articulated in Justice Souter's Chavez concurrence, an opinion joined in full by Justice Breyer. According to Justice Souter, though "the text of the Fifth Amendment . . . focuses on courtroom use of a criminal defendant's compelled, self-incriminating testimony," 40 out-of-courtroom "extensions" of the Fifth Amendment's guarantee are constitutional decisions. ${ }^{41}$ Holdings that bar the compulsion of testimonial evidence in a civil proceeding ${ }^{42}$ require a grant of immunity to access a witness's silence-protected testimony, ${ }^{43}$ or condition the admissibility of statements obtained by the police on the presence of

3 Chavez v. Martinez, 538 U.S. 760, 772 (2005).

34 See 542 U.S. 630, 638-40 (2004).

35 Id. at 639.

36 Id. at 639-40.

37 Id.

38 Id. at 639 (citing Justice Souter's concurrence in Chavez, 538 U.S. at 778).

39 Between Chavez and Patane, the justices that joined Justice Thomas's plurality opinions included Chief Justice Rehnquist and Justices O'Connor and Scalia. Justices Souter and Breyer joined those opinions in part. Of these members, only Justices Thomas and Breyer presently sit on the Court.

40 Chavez, 538 U.S. at 777.

41 Id.

42 McCarthy v. Arndstein, 266 U.S. 34, 40 (1924).

43 Kastigar v. United States, 406 U.S. 441, 446-47 (1972). 
warnings ${ }^{44}$ are no doubt grounded in the Clause, according to Justice Souter. ${ }^{45}$

However, the constitutional character of these "extensions" cannot, on their own, award a plaintiff the exact remedy sought under $\S 1983$. Absent a "limiting principle or reason to foresee a stopping place short of liability in all" cases where the government violated any one of these "extensions," gifting plaintiffs with a $\S 1983$ remedy for every Miranda violation is inappropriate. ${ }^{46}$ Put another way, Justices Souter and Breyer both agreed that permitting relief under $\S 1983$ for Miranda violationsan addition to Miranda's exclusionary rule - was not "necessary in aid of the [Clause's] basic guarantee." 47

The second view, argued by Justice Kennedy, adopts a more expansive vision of the Clause. ${ }^{48}$ Unlike Justice Souter, Justice Kennedy, joined in parts by Justices Stevens and Ginsburg, emphasized that the constitutional guarantee of the Clause is "traduced the moment torture or its close equivalents are brought to bear." 49 The Clause provides "more than mere assurance that a compelled statement will not be introduced against its declarant in a criminal trial." 50 Instead, it is a substantive restraint on the conduct of government, with violations potentially accruing well before the defendant arrives in a courtroom (or is even a defendant). ${ }^{51}$

Importantly situated between Justices Souter's and Kennedy's opinions is meaningful common ground which can provide guidance to the Court's holding in Vogt. For instance, both Justices Souter and Kennedy view the Court's Miranda doctrine as a constitutional doctrine. ${ }^{52}$

44 See generally Miranda v. Arizona, 384 U.S. 436 (1966).

45 Chavez, 538 U.S. at 777-78 (explaining that though outside the Fifth Amendment's core, these extensions are a complementary protection to that core).

46 Id. at 779 .

$47 \mathrm{Id}$.

48 That said, like Justice Souter, Justice Kennedy did not find merit in allowing a petitioner's $\S 1983$ claim to continue since the exclusion of the unwarned statements was already a sufficient remedy. See $i d$. at 790 (Kennedy, J., dissenting) ("The exclusion of unwarned statements, when not within an exception, is a complete and sufficient remedy.")

49 Id. at 789-90.

$50 \quad I d$. at 791 .

51 Id. at 791 ("The Clause protects an individual from being forced to give answers demanded by an official in any context when the answers might give rise to criminal liability in the future."). See also Michael J. Sydney Mannheimer, Ripeness of SelfIncrimination Clause Disputes, 95 J. CRIM. L. \& CRIMINOLOGY 1261, 1277 (noting that some cases have established that the privilege against self-incrimination "is a distinct and independent right not to have the government compel one to disclose self-incriminatory information in the first place.").

52 Chavez, 538 U.S. at 777-78 (Souter, J., concurring) ("we can make sense of a variety of Fifth Amendment holdings ... [ [such as] conditioning the admissibility on warnings and waivers to promote intelligent choices and to simply subsequent inquiry into 
Indeed, both agreed that since remedies define the scope of the constitutional rights they protect, those remedies are themselves constitutional. ${ }^{53}$ At the same time, both Justices agreed that a violation of a constitutional remedy can, but need not always, support a $§ 1983$ claim. ${ }^{54}$ A violation of a Fifth Amendment rule can give rise to a $\$ 1983$ claim insofar as a $\S 1983$ remedy would advance the purpose(s) of the Clause. ${ }^{55}$ If the present remedy (exclusion) is already effective, both Justice Souter and Justice Kennedy thought, the need to bolster the Clause with a separate civil remedy is not required.

If this shared ground accurately describes the Court's current thoughts on this subject, then Vogt's argument, that the use of his compelled testimony in a pretrial hearing should entitle him a $\S 1983$ remedy, may depend less on the constitutional nature of the immunity that attached to his statement. Rather, the Court, guided by the overlap between Justices Souter and Kennedy in Chavez, may find Vogt's case to depend on the need for an additional civil remedy to defend the privilege- $\mathrm{a}$ question that would likely be answered in the negative if the Court finds that immunity (and its use and derivative use prohibition) is already a satisfactory remedy.

\section{THE DIFFERENCE WITH IMMUNITY}

This remedial discretion located at the intersection of Justice Souter's and Justice Kennedy's opinions in Chavez, however, may have less purchase in Vogt. ${ }^{56}$ That is because Vogt, unlike Chavez, implicates a related yet distinct subject: immunity. This difference may mean that violations of immunity, including pretrial violations of the same, can give rise to a $\S 1983$ remedy.

To Justice Thomas, however, immunity is no different than Miranda. Justice Thomas, again in Chavez, insisted that "a prior grant of immunity is essential to memorialize the fact that the testimony had indeed been

voluntariness"); Id. at 790 (Kennedy, J., concurring in part, dissenting in part) ("The Miranda warning, as is now well settled, is a constitutional requirement adopted to reduce the risk of a coerced confession and to implement the Self-Incrimination Clause.”)

$53 \mathrm{Id}$.

54 See Chavez, 538 U.S. at 777 (Souter, J., concurring) ("To recognize such a constitutional cause of action for compensation would, of course, be well outside the core of Fifth Amendment protection, but that alone is not a sufficient reason to reject Martinez's claim."); id. at 790 (Kennedy, J., concurring in part, dissenting in part) ("The exclusion of unwarned statements, when not within an exception, is a complete and sufficient remedy.").

55 For a list of the Clause's purposes, see Murphy v. Waterfront Comm'n of N.Y. Harbor, 378 U.S. 52, 55 (1967) (listing the "policies of the privilege" to include seven separate and distinct "aspirations").

56 See supra notes 51-54. 
compelled and therefore protected from use against the speaker in any 'criminal case'." ${ }^{57}$ But that is all; both immunity and Miranda warnings, he emphasized, serve to "safeguard a constitutional right," whose importance only arises after a criminal trial has begun. ${ }^{58}$ Thus, on their own, immunity and Miranda warnings lack any constitutional significance. ${ }^{59}$ The Government's failure to honor either rule, even before a criminal case has begun, therefore, does not violate the Fifth Amendment and thus cannot provide the basis for a $\S 1983$ remedy.

But if this characterization of Miranda and immunity as nonconstitutional prophylactic rules is accurate, then it must also be the case that Congress can modify or wholly reject these doctrines altogether. After all, as long as the government does not use involuntary, selfincriminatory testimony against a defendant at trial, there is nothing in the Fifth Amendment that requires a preemptive remedy like immunity. ${ }^{60}$ However, this view, especially in the case of immunity, directly confronts the Court's holding in Kastigar v. United States. ${ }^{61}$ Kastigar probed the constitutionality of the new federal immunity statute. ${ }^{62}$ The Court's conclusion was that the newly-enacted statute ${ }^{63}$ is "as comprehensive as the protection afforded by the privilege." ${ }^{\prime 4}$ Thus, to be consistent with the Clause, neither Congress nor state legislatures could install an immunity standard less protective than use/derivative use immunity. ${ }^{65}$

Moreover, Justice Thomas's view is a significant departure from traditional views of the Clause itself. Before Chavez, it was well understood that the Clause protected two separate and distinct rights. In addition to barring the use of a defendant's compelled statements against her at trial, the Clause also barred "the government from using compulsion

57 Chavez, 538 U.S. at 771-72.

58 Id. at 772 .

59 Id. Of course, Thomas likely asserted this position to be consistent within his Chavez holding. If the privilege is only a trial right and if Miranda is merely a pretrial safeguard, then the same must be true for immunity. Any distinction between the two rules-with immunity representing something more serious than a pretrial safeguard - and his opinion could topple.

60 Id. at 773.

61 Kastigar, 406 U.S. 441, 442 (1972). See also Brown v. Walker, 161 U.S. 591, 59394 (1896); Ullman v. United States, 350 U.S. 422, 438 (1956) (both explicitly visiting the constitutionality of immunity doctrines, with Justice Frankfurter commentating in Ullman that immunity statutes have "become [a] part of our constitutional fabric[.]").

62 Kastigar, 406 U.S. at 442.

6318 U.S.C. $\S \S 6002-6003$.

64 Kastigar, 406 U.S. at 449.

65 Id. 
to obtain incriminating information from any person."66 Put differently, the Clause is implicated anytime an individual is made to serve as a "witness against himself," regardless of whether the witnessing was at the speaker's own criminal trial or elsewhere. The term "witness," in other words, is not limited to criminal trials alone and is not modified or defined by its nearby companion: "any criminal case." Instead, the term "any criminal case" is relevant only to whether the witness can properly invoke the privilege. The Clause's reference to "any criminal case" is present to decide a witness's ability to invoke the privilege regardless of whether an actual criminal trial does in fact follow.

Finally, Justice Thomas's view sits in tension with the way parties can litigate claims implicating the privilege against self-incrimination. ${ }^{67}$ Typically, if a witness before a civil, administrative or Congressional inquiry invokes her privilege and her inquirers doubt the justification behind the invocation, she does not have to wait for a criminal prosecution against her to begin (or worse, to end) to resolve the dispute over her invocation. ${ }^{68}$ Instead, if a dispute over the witness's invocation of the privilege arises, the parties can resolve their dispute in court immediately, in the form of a contempt proceeding brought against that witness. ${ }^{69}$ This way, the witness can avoid the "cruel trilemma" of either (1) having to testify in fear of criminal incrimination, (2) remain silent and risk penalty for contempt, or (3) lie on the stand and risk perjury. ${ }^{70}$ A preliminary hearing on the merits of the invocation, therefore, can reassure the witness that her statements will not be used against her. More significantly, this procedure underscores that the privilege's relevance begins well before a criminal trial starts.

Yet, the plurality's position in Chavez suggests that the contempt charge must wait until there is a subsequent criminal trial at which the prosecutor uses the witness's compelled, involuntary statements. ${ }^{71}$ Only then, according to the Court, is the constitutional claim that underlines the contempt charge ripe for adjudication. ${ }^{72}$ But it would be odd to hold a witness in contempt until and ultimately if there is a subsequent criminal trial against the witness at which point she can litigate the merits of her

66 Baxter v. Palmigiano, 425 U.S. 308, 327 (1976); see Garner v. United States, 424 U.S. 648, 653 (1976) ("the privilege protects against the use of compelled statements as well as guarantees the right to remain silent absent immunity.")

67 U.S. CONST. amend. V.

68 Mannheimer, supra note 51 at 1268.

69 See United States v. Mandjuano, 425 U.S. 564, 575 (1976).

70 See Murphy v. Waterfront Comm'n of N.Y. Harbor, 378 U.S. 52, 55 (1964) (“our unwillingness to subject those suspected of crime to the cruel trilemma of self-accusation, perjury or contempt.").

71 Chavez, 538 U.S. at 771-73.

72 Id. 
invocation. ${ }^{73}$ Indeed, such procedural sequence would undermine the very import of the Clause-relieving a witness from making incriminatory statements.

However persuasive this counter-argument may be, these cases and procedures do not answer the question of whether, despite immunity's promise, a $\S 1983$ plaintiff can receive relief when the government breaches its obligation not to use any compelled testimony or its fruits against her. After all, in the mold of Justice Souter and Justice Kennedy's thoughts in Chavez, immunity's own exclusionary rule may be a sufficient remedy, undermining the need for any separate $\S 1983$ relief. ${ }^{74}$ Wellestablished distinctions between the Miranda and immunity doctrines, however, suggest that in cases of immunity a $\S 1983$ remedy may be appropriate.

Indeed, the first key distinction between Miranda warnings and immunity is the way in which each arises. "[T]he Miranda warning . . . is a constitutional requirement adopted to reduce the risk of a coerced confession."75 The police's delivery of the warning does not etch in stone every statement that springs from a custodial interrogation as coercive or involuntary. Instead, the warning serves as a precaution to the interviewee and signals to him that he can freely invoke certain constitutional rights. ${ }^{76}$ Miranda's exclusionary rule therefore does not principally exist to show that un-Mirandized testimony was involuntary. ${ }^{77}$ It exists, in large part, to encourage the police to act a certain way (i.e., deliver the warnings and abstain from coercive interrogation practices). ${ }^{78}$

Immunity, on the other hand, does not arise preemptively. It emerges from the deliberate choice of the witness, who reasonably fears the potential incriminatory use of her own words,${ }^{79}$ not to reveal her thoughts. Accordingly, immunity is the currency the government must use to purchase a witness's constitutionally-protected silence. ${ }^{80}$ Its presence

73 This surely raises a perplexing question: if a witness is held in contempt but there is no subsequent criminal trial at which she can litigate her disputed invocation of silence and thus the contempt charge, what happens to that contempt charge?

74 See Chavez, 538 U.S. at 790 (Kennedy, J., dissenting).

75 Id. at 790 (citations omitted) (emphasis in original).

76 Miranda, 384 U.S. at 466-67.

77 See Oregon v. Elstad, 470 U.S. 298, 306-08 (1985).

$78 I d$. at 308 ("We believe that this reasoning applies with equal force when the alleged 'fruit' of a noncoercive Miranda violation is neither a witness nor an article of evidence but the accused's own voluntary testimony. As in [Michigan v.] Tucker, the absence of any coercion or improper tactics undercuts the twin rationales-trustworthiness and deterrence-for a broader rule.")

79 Hoffman v. United States, 341 U.S. 479, 486 (1951) (holding that a reasonable belief of incrimination in a criminal case is necessary to invoke the Clause's silence).

80 See Kastigar v. United States, 461 U.S. 441, 446-47 (1972). 
signifies that any testimony protected by it is, by definition, involuntary. ${ }^{81}$ And for that reason, the corresponding exclusion of immunized testimony exists to ensure that the witness is in approximately the same position as if she had remained silent. ${ }^{82}$ Immunity's objective is not to reduce the risk of compulsion itself (as is the case with Miranda), but instead is to signal to prosecutors and investigators that they cannot use, directly or derivatively, any of the witness's compelled testimony. ${ }^{83}$

Considering this protection, immunity is far more protective than Miranda warnings. Kastigar's use/derivative use immunity protects the speaker's words from direct use in a trial as well as from derivative use in any subsequent criminal investigation or prosecution. ${ }^{84}$ To that end, Kastigar stressed that even out-of-courtroom uses of immunized testimony can violate immunity, particularly if it guides the government to leads or evidence it otherwise would not have uncovered. ${ }^{85}$ Hence, an out-of-court use of immunized testimony can vacate an indictment ${ }^{86}$ or, if a court holds a post-trial Kastigar hearing, ${ }^{87}$ reverse a conviction..$^{88}$

By contrast, since the Court first announced the Miranda doctrine, it has carved out exceptions to the doctrine. These carve-outs emphasize that the Miranda doctrine's scope, unlike the Court's treatment of immunity, is only as good as the goal (thwarting coercive interrogation practices) it serves. Thus, in the context of Miranda warnings, "the need for answers to questions in a situation posing a threat to the public safety outweighs the need for the prophylactic rule protecting the Fifth

81 New Jersey v. Portash, 440 U.S. 450, 459 (1979) ("Testimony given in response to a grant of legislative immunity is the essence of coerced testimony. In such cases there is no question whether physical or psychological pressures overrode the defendant's will[.]").

82 Kastigar, 406 U.S. at 457 (citations omitted) (immunity's aim is to place "the witness ... in substantially the same position as if the witness had claimed his privilege.").

83 Chavez, 548 U.S.at 771-72 ("[A] grant of immunity is essential to memorialize the fact that the testimony had indeed been compelled.")

84 Kastigar, 441 U.S. at 460.

85 Id. (citing 18 U.S.C. $\$ 6002$ ).

86 See, e.g., United States v. Slough, 641 F.3d 544 (D.C. Cir. 2011) (remanding the case for further adjudication and noting that an indictment can be dismissed should the trial court find that the indictment was based on compelled testimony).

87 See United States v. Allen, 160 F.Supp.3d 684, 687 (2016) (noting that it is Second Circuit practice to hold a Kastigar hearing "following the conclusion of the defendants" trials"). A Kastigar hearing is a hearing where the government bears the "heavy burden" of affirmatively proving that all its trial evidence is independent of any compelled testimony. Kastigar, 406 U.S. at 461-62. A trial court may also make this finding during or after the trial. United States v. North, 910 F.2d 843, 854 (D.C. Cir. 1990) ("The Kastigar hearing may be held 'pre-trial, post-trial, mid-trial (as evidence is offered), or [through] some combination of these methods,' although '[a] pre-trial hearing is the most common choice."') (alteration in original).

88 See, e.g., United States v. Conti, 2017 WL 3040201 (2d Cir. July 19, 2017). 
Amendment's privilege against self-incrimination." 89 The same, however, is not true with immunity. The Court has not permitted the government to breach immunity for public safety reasons.

Similarly, an un-Mirandized statement made by the defendant is admissible at trial to impeach her. ${ }^{90}$ For example, in Harris v. New York, the Court noted that "[i]t does not follow from Miranda that evidence inadmissible against an accused in the prosecution's case in chief is barred for all purposes." 91 Meanwhile, the same is not true with immunity. In fact, the Supreme Court in New Jersey v. Portash explicitly distinguished immunity from Miranda when it wrote that "a defendant's compelled statements, as opposed to statements taken in violation of Miranda, may not be put to any testimonial use," including impeachment uses, that lay outside the prosecution's case-in-chief. ${ }^{92}$ Since Portash, the Court has recognized a key substantive difference between immunity and Miranda warnings: while one (Miranda) flexes according to the prophylactic purpose it serves, the other (immunity) is absolute, barred from bending or adjusting to each situation. ${ }^{93}$

In short, there are three takeaways from this discussion. First, immunity is more protective of individuals than Miranda. The response to a breach of immunity is illustrative. Any direct or indirect use of compelled testimony, however tangentially related to the trial evidence, may be grounds to nullify the entire case. Uses of un-Mirandized testimony, in contrast, do not invite such strong medicine-a sensible outcome given that un-Mirandized testimony, on its own, is not an unimpeachable, irreversible marker of that testimony's involuntariness. This voluntary/involuntary distinction underscores why the outcome in Chavez (the denial of $\S 1983$ relief) may not replicate itself in Vogt, where the testimony at issue is compelled.

Second, considering the purpose of immunity, adding a civil remedy atop the already robust protection of immunity is likely appropriate. This is no doubt made clear by the fact that the government may violate immunity even when no subsequent trial of the immunized person occurs. In other words, the Court's immunity jurisprudence has emphasized that there is no constitutional difference between pretrial violations and trial

89 New York v. Quarles, 467 U.S. 649, 657 (1984).

90 Harris v. New York, 401 U.S. 222, 226 (1971).

91 Id. at 224 (adding that the shield provided by Miranda cannot be perverted into a license to use perjury by way of a defense, free from the risk of confrontation with prior inconsistent utterances).

92440 U.S. 450, 459 (1979) (citation omitted).

93 See also Elstad, supra note 58 at 317-18 (holding that the Fifth Amendment does not require the suppression of a confession made after proper Miranda warnings solely because an earlier voluntary, but unwarned, admission of the defendant). 
violations of immunity. To the extent that a trial violation of immunity can raise a $\S 1983$ action - a proposition that even Justice Thomas's opinion in Chavez would endorse - then so too must pretrial violations of it. ${ }^{94}$ Arguably, this is true even if no subsequent trial follows. ${ }^{95}$

Third, since immunity is as much a constitutional guarantee as the Clause's undisputed trial right, the scope of the phrases "any criminal case" or "a witness against himself" must be as extensive as the uses and derivative uses barred under immunity. The Supreme Court, in other words, would pervert the Clause should they hold, on the one hand, that an indictment's or case's dismissal is necessary where a prosecutor violates immunity outside the courtroom, but then, on the other hand, limit violations of the Clause only to events inside the courtroom and at trial. Unless the Court wishes to unwind the strong positions it has taken with respect to its immunity doctrine since Kastigar, the two concepts must be coextensive with one another.

\section{CLOSING THE LOOP}

Unfortunately, these points alone do not answer whether an immunized statement's use in a pretrial hearing violates immunity and therein the Clause. Thus, to determine if Vogt is entitled to relief, the Court should (and must) decide if the use of a compelled statement in a pretrial probable cause hearing is in fact a barred use under immunity. At bottom, this is a question about the scope of Kastigar's protection.

The chief hurdle in answering this question is deciphering exactly what the Court meant when it barred uses and derivative uses in Kastigar. Today, federal courts are divided on that subject. Some courts have stressed that to uphold the language and spirit of Kastigar, the government can make no uses of immunized testimony whatsoever, regardless of whether that is at or before trial. ${ }^{96}$ For instance, one circuit has held that a

94 There are no published cases in which a $§ 1983$ plaintiff has successfully sued a municipality for the subsequent use of her compelled, immunized testimony at trial. Thus, there is no direct case to cite for that proposition. But the suggestion that Justice Thomas, would support $\$ 1983$ relief, at least in theory, derives from his dicta in Chavez. See Chavez, 538 U.S. 760, 770 (2005) (" . . a violation of the constitutional right against selfincrimination occurs only if one has been compelled to be a witness against himself in a criminal case.") (emphasis in original).

95 As discussed in Part IV below, this is the central question in this case: whether pretrial violations of immunity, with no subsequent criminal trial at which the pretrial violations are revealed, is enough to raise a $\S 1983$ claim.

96 See United States v. Semkiw, 712 F.2d 891, 894-95 (3d Cir. 1983) (finding that the government did not discharge its heavy Kastigar burden in part because the assigned trial attorney had "access" to compelled testimony). See also United States v. Pantone, 634 F.2d 716, 721 (finding that the government met its Kastigar burden partly because "a primary concern of Kastigar and the Department of Justice Guidelines, that mere access to 
trial prosecutor's inadvertent exposure to immunized testimony prior to trial was sufficient to violate immunity, even when all of the government's trial evidence was provably independent of any immunized testimony. ${ }^{97}$ This sweeping position vindicates one reading of Kastigar: immunity must leave the defendant "in substantially the same position as if the witness ... claimed his privilege in the absence of a state grant of immunity." 98 Any advantages prosecutors take from immunized testimony - whether for strategic or evidentiary purposes - are prohibited.

Another group of federal circuits disagree with this expansive reading. These courts hold that immunity is strictly contained to "evidentiary" uses of any immunized testimony. ${ }^{99}$ Where the government can prove the independence of its trial evidence from the defendant's immunized testimony, any other uses - however significant to the case's presentation - are allowed. Prosecutorial uses of immunized testimony that are not a "link in the chain of [the trial] evidence" are permitted. ${ }^{100}$ These uses can include "focusing the investigation, deciding to initiate prosecution, refusing to plea-bargain, interpreting evidence, planning cross-examination,"101 inducing another witness to speak, ${ }^{102}$ and other general trial strategy. Allowing these uses, these circuits hold, acknowledges another point made by the Kastigar Court: the mere presence of state-granted immunity should not alone bar the prosecution of a previously-compelled defendant. ${ }^{103}$ Exposure to immunized testimony, to the extent it has not tainted the trial evidence's independence, is not fatal to the government's case. Whether Vogt can receive relief likely hangs on which view of immunity the Court takes. If it adopts the first view, the use of Vogt's immunized statement in a probable cause hearing likely violates the Clause. This is especially so since the State of

\footnotetext{
immunized information may catalyze chains of investigation or subliminally affect decisions to prosecute, is not even in issue here").

97 United States v. McDaniel, 482 F.2d 305, 309-10 (8th Cir. 1973).

98 Kastigar v. United States, 406 U.S. 441,457 (1972).

99 United States v. Serrano, 870 F.2d 1, 17 (1st Cir. 1989); United States v. Cozzi, 613 F.3d 725, 729 (7th Cir. 2010) (citing United States v. Schmidigall, 25 F.3d 1523, 1529 (11 ${ }^{\text {th }}$ Cir. 1994)); United States v. Helmsley, 941 F.2d 71, 82 (2d Cir. 1991); United States v. Mariani, 851 F.2d 595, 600 (2d Cir. 1988) ("[W]e have held that the government must prove that it 'relied solely' on evidence from legitimate independent sources.'”); United States v. Byrd, 765 F.2d 1524, 1529-30 (11th Cir. 1985) ("Thus, in the case sub judice, the government's burden under Kastigar was simply to prove that the evidence presented to the grand jury (and ultimately the evidence utilized at trial) was derived from legitimate, independent sources.").

100 United States v. Hubbell, 530 U.S. 27, 38 (2000).

101 McDaniel, 482 F.2d at 311.

102 United States v. Mapes, 59 MJ 60, 69 (2003).

103 Kastigar, 406 U.S. at 453 ("The privilege has never been construed to mean that one who invokes it cannot subsequently be prosecuted.").
} 
Kansas's decision to bring a criminal matter against Vogt relied in part on Vogt's immunized statements provided by the City. ${ }^{104}$ Vogt, in short, was made worse off by the state's use of his immunized statements. In contrast, a Court that adopts the second view may find the absence of any violation. The absence of a criminal trial, as was the case in Vogt, means the absence of any evidentiary uses. Thus, because there was no trial evidence, the government is not required to prove its evidence's independence. Consequently, with no evidence, there can be no immunity violation, and this is the case no matter how clear the government's pretrial use of any immunized testimony was or how obvious its intent to use (directly or derivatively) that immunized testimony at trial was.

Further instructing which one of these views the Court may take in Vogt is a separate question: when precisely does an immunity violation ripen? If the Court holds that an immunity violation only ripens at trial and not before-a view that comports with Justice Thomas's Chavez opinion that a violation of the Clause can only occur after the initiation of criminal proceeding - the Court will likely favor the second approach. Vogt, therefore, may not be entitled to the relief he seeks. This view has some support. In perhaps the most (in)famous case implicating the boundaries of immunity, United States v. North, the D.C. Circuit was asked to determine if certain trial witnesses' exposure ${ }^{105}$ to the defendant's congressionally-compelled testimony qualified as a breach of immunity. ${ }^{106}$ Ultimately, the D.C. Circuit held that the exposure was a barred "indirect evidentiary" use, ${ }^{107}$ with the use occurring when the tainted witness was put on the stand at trial, not at the time of the witnesses' exposure. ${ }^{108} \mathrm{~A}$ violation could not ripen, the court implied, until the trial.

But this view may not comport with other cases, which suggest a breach can also occur whenever the immunized statements certify a case to proceed to trial. Most notably, if immunized words of the indicted defendant are used (directly or derivatively) before a grand jury to return that indictment, the indictment must be dismissed. ${ }^{109}$ In like manner, a

104 Vogt, 844 F.3d 1235, 1250 (10th Cir. 2017).

105 This exposure was independent of any prosecutorial conduct. In other words, the prosecution did not participate, encourage, or condone the witnesses' exposure to the defendant's compelled testimony. Rather, the witnesses watched North's testimony on their own.

106 United States v. North, 910 F.2d 843, 853 (D.C. Cir. 1990).

107 Id. at 860.

108 Id. at 856-58.

109 See, Higazy v. Templeton, 505 F.3d 161, 171, 173 (2d Cir. 2007) (noting that the use of a coerced statement before a trial or grand jury can violate the Fifth Amendment); Stoot v. City of Everett, 582 F.3d 910, 925 (9th Cir. 2009) (noting that where "[a] coerced statement ... has been relied upon to file formal charges against the declarant ..." the Fifth Amendment has been violated). 
court's reliance on immunized testimony in a probable cause hearing, which like a grand jury certifies the case's merits, may be satisfactory grounds for an immunity violation. Barred uses, therefore, occur at hearings that initiate a criminal case, not just at the criminal trial itself. ${ }^{110}$ Consequently, an immunity violation can ripen before a trial begins, especially if the immunized testimony is used to certify a case's merits. Applied in Vogt, the absence of any subsequent trial may not undermine Vogt's $\S 1983$ claim that the City violated his privilege against selfincrimination; indeed, Vogt may therefore be entitled to relief.

\section{CONCLUSION}

Einstein once suggested that if he had an hour to correctly solve a problem, he would spend the first 55 minutes trying to ask the right question and the remaining five minutes to solve it. If Einstein's wisdom is correct, then the Court may need to spend more time finding the right question to ask in Vogt. As this Essay has argued, the correct question to ask in Vogt is not what the Founders meant when they used the words "any criminal case" or "witness against himself." Rather, the correct inquiries are, first, is the Court's immunity doctrine a constitutional guarantee? Second, if immunity is in fact a constitutional guarantee, should the interpretation of the phrases "any criminal case" and "a witness against himself" be as extensive as the bounds of use/derivative use immunity? And third, does that immunity bar direct or indirect uses of immunized testimony in a pretrial probable cause hearing, particularly when there was no subsequent criminal trial (or conviction) that followed?

While the first and second questions' answer should be "yes," the third question unfortunately does not produce a clear answer. Thus, it should be the focus of the Court's visit in Vogt. Indeed, as discussed above, circuits are split over the protection guaranteed under immunity. The absence of any criminal trial in the record here no doubt complicates the case. It requires the Court to decide not only the type of use (evidentiary or non-evidentiary) made in Vogt, but whether, in the absence of any actual trial, whether that use alone has ripened into a barred use under the Clause. Whatever the outcome, probing the scope of immunity is necessary, this Essay believes, to decide the fate of Vogt's $\S 1983$ claim.

110 Note that if this is the case, then the extension of "any criminal case" to bail hearings or even suppression hearings may not be appropriate. Unlike a grand jury or probable cause hearing, these hearings have little connection to the case's merits or its continuance. In this sense, use/derivative use immunity may permit the compelled statement's use(s) in bail or suppression hearings. This permission, however, may turn on the breadth of a nonevidentiary use of immunized testimony, a topic not discussed thoroughly here. 
Regardless of the outcome, addressing these questions will provide much-needed clarity to prosecutors and the defense bar about and what the government can (or cannot do) with immunized testimony. Should the Court address these issues, any decision will likely come as welcomed guidance, particularly as immunity becomes increasingly significant amidst probing independent investigations, the rise in complex criminal prosecutions that often rely on witness's immunized testimony, an increase in cross-border criminal prosecutions that may intersect with foreign-compelled testimony, ${ }^{111}$ and a continued, determined focus of individual, as opposed to corporate, criminal responsibility by the Justice Department. ${ }^{112}$

111 See United States v. Conti, 864 F.3d 63, 82 (2d Cir. 2017) (holding that testimony compelled by a foreign sovereign, independent of any U.S. government action, implicates the Fifth Amendment's privilege against self-incrimination when that involuntary testimony is used in a U.S. criminal case). See also Neal Modi, Note, Towards an International Right Against Self-Incrimination: Expanding the Fifth Amendment's Compelled to Foreign Compulsion, 103 VA. L. REV. 961, 968 (2017) (noting the rise in cross-border criminal investigations in which foreign sovereigns have compelled a potential defendant under threat of sanction).

112 See Sari Horwitz, Justice Dept. to Focus on Individuals in Cases of Corporate Misconduct, Wash. $\quad$ Post $\quad$ (Sept. $10, \quad$ 2015), https://www.washingtonpost.com/world/national-security/justice-dept-to-focus-onindividuals-in-cases-of-corporate-misconduct/ 2015/09/10/c14b0ec0-57db-11e5-abe927d53f250b11_story.html. 